\title{
Biblioteka krymskotatarska w Symferopolu
}

Streszczenie. Artykuł jest próbą przedstawienia procesu odradzania się biblioteki narodowej krymskotatarskiej mniejszości etnicznej w wieloetnicznym środowisku Krymu. Omówiono ważniejsze wydarzenia z ponad 25-letniej historii tworzenia biblioteki oraz jej obecną strukturę i działalność: prace biblioteczne, usługi, działalność oświatową, metodyczną, naukową i wydawniczą.

SŁowA KLuczowe: Krym, Tatarzy krymscy, Republikańska Biblioteka Krymskotatarska im. I. Gasprinskiego, funkcje biblioteki, usługi biblioteczne.

\section{Wstęp}

Polska literatura przedmiotu dotycząca Tatarów krymskich jest dość obszerna. Selim Chazbijewicz poświęcił im dwie monografie ${ }^{1}$ wydane w 2001 roku. W czasopismach naukowych i popularnonaukowych oraz w prasie opublikowano wiele artykułów naświetlających różne aspekty życia tego narodu. Najsłabiej omówione jest dziedzictwo kulturowe. Brakuje natomiast opracowania na temat biblioteki krymskotatarskiej. Niniejszy artykuł ma na celu wypełnienie tej luki i pokazanie, jak współcześnie powstaje zupełnie od podstaw - i funkcjonuje w środowisku wieloetnicznym - biblioteka o charakterze narodowym.

${ }^{1}$ S. Chazbijewicz, Awdet czyli powrót. Walka polityczna Tatarów krymskich o zachowanie tożsamości narodowej i niepodległość państwa po II wojnie światowej, Olsztyn 2001; idem, Tatarzy krymscy. Walka o naród i wolna ojczyznę, Poznań-Września 2001. 


\section{Podstawowe informacje o Tatarach krymskich}

Po aneksji Chanatu Krymskiego (1783) polityka kolonialna Rosji carskiej, niezwykle dotkliwa w odniesieniu do rdzennej ludności Krymu - masowe wysiedlenia, ograniczanie stanu posiadania i wolności religijnej, likwidacja tradycji i kultury, rusyfikacja ${ }^{2}$ - skutkowała falami emigracji głównie do państwa osmańskiego (w sumie ok. 1,2 mln). Po burzliwym okresie wojny domowej i opanowaniu Krymu przez bolszewików w październiku 1921 roku utworzono Krymską Autonomiczną Socjalistyczną Republikę Radziecką (KASRR) jako integralną część Rosji radzieckiej. KASRR przetrwała do 1946 roku, kiedy to została przekształcona w obwód krymski. W latach NEP-u³ (1923-1928) Tatarzy cieszyli się w niej dość dużymi swobodami („tataryzacja”). Po tym okresie nastąpiły bolesne represje stalinowskiej polityki narodowościowej. Jej kulminacją był zarzut kolaboracji z hitlerowskim okupantem - zasadny w odniesieniu tylko do pewnej części ludności tatarskiej. ${ }^{4}$ W rezultacie wydalono z Krymu cały naród, przez wieki zamieszkujący półwysep. Na rozkaz Stalina w maju 1944 roku Tatarów deportowano do Azji Środkowej, przede wszystkim do Uzbekistanu, i na dziesięciolecia pozbawiono ojczyzny. Z ponad 190000 deportowanych Tatarów krymskich ok. $46 \%$ zmarło $\mathrm{w}$ transporcie i w pierwszych latach wygnania.

Tatarzy krymscy są obecnie trzecim pod względem liczebności - po Rosjanach i Ukraińcach - narodem zamieszkującym Krym (ok. 260000 osób, co stanowi ok. 13\% ludności).

${ }^{2}$ S. Chazbijewicz, Awdet czyli powrót..., s. 26-32.

${ }^{3} \mathrm{NEP}$ - nowa polityka ekonomiczna, doktryna polityki gospodarczej Rosji radzieckiej i później ZSRR w latach 1921-1929, rodzaj gospodarki mieszanej lub kapitalistycznej; NEP oznaczał zmianę polityki gospodarczej rządu radzieckiego, rezygnację z komunizmu wojennego i wprowadzenie rynkowych mechanizmów gospodarczych; umożliwiał podejmowanie małych prywatnych przedsięwzięć $\mathrm{w}$ rolnictwie i usługach, zezwalał też na koncesjonowaną działalność gospodarczą międzynarodowych przedsiębiorstw.

${ }^{4}$ W czasie okupacji Krymu (1941-1944) część ludności tatarskiej wykazała gotowość do współpracy z Niemcami w nadziei na realizację przy pomocy okupantów aspiracji narodowych. W niemieckich formacjach militarnych (wojskowych, policyjnych i oddziałach pomocniczych tzw. samoobrony) służyło ok. 20000 osób. Tatarzy krymscy wchodzili w skład lokalnej administracji, mieli też przywileje w zakresie edukacji, kultury i wolności religijnej (zob. S. Ciesielski, Masowe deportacje ludności w ZSRR: Deportacje z Krymu, w: Dzieje Najnowsze. Serwis historyczny dotyczacy historii Polski, Rosji, Europy Wschodniej, http:// www.sciesielski.republika.pl/sov-dep/krym1.html\#1 [dostęp: 10.05.2016]. Postawa Tatarów nie była jednolita. Powołując się na A. Fishera, Chazbijewicz podaje, że 53000 Tatarów krymskich walczyło na froncie w Armii Czerwonej, a 12000 brało udział w ruchu partyzanckim i w ruchu oporu. Wielu z nich odznaczono Orderem Bohatera Związku Radzieckiego (zob. S. Chazbijewicz, Awdet czyli powrót..., s. 89-91). 
Tradycyjnie Tatarzy krymscy są wyznawcami islamu, a ich językiem ojczystym jest krymskotatarski ${ }^{5}$ należący do kipczackiej grupy językowej w obrębie rodziny języków turkijskich (tureckich). Do zapisu używa się alfabetu łacińskiego lub cyrylicy.

Po wydarzeniach z początku 2014 roku $^{6}$ nasiliły się represyjne działania wobec nieprzychylnych władzom rosyjskim działaczy krymskotatarskich na Krymie: zlikwidowano niezależne instytucje i media, a samorząd Tatarów krymskich, Medżlis, został uznany za organizację ekstremistyczną. Po zajęciu Krymu przez Rosję terytorium półwyspu opuściło ponad 9000 Tatarów, głównie osoby aktywne politycznie, niegodzące się z aneksją i zagrożone represjami. Tym, którzy pozostali, a szczególnie środowiskom związanym lub sympatyzującym z prorosyjską partią narodową Milli Firka stojącą $\mathrm{w}$ opozycji do Medżlisu ${ }^{7}$, przypadło $\mathrm{w}$ udziale zmierzenie się z koniecznością wypracowania poprawnych stosunków pomiędzy stronami w nowej sytuacji, tak by nie zaprzepaścić dotychczasowych zdobyczy i utrzymać się w odzyskanej po przymusowym wysiedleniu ojczyźnie.

\section{Biblioteki tatarskie na Krymie od XVI wieku do 1990 roku}

\section{W Chanacie Krymskim}

Początków wielowiekowej historii bibliotek krymskotatarskich należy doszukiwać się W XVI wieku. W 1500 roku chan Mengli I Girej (1445-1515) założył w ówczesnej stolicy chanatu - Sałaczyku pod

${ }^{5}$ Konstytucja Republiki Krymu przyjęta przez Radę Państwa Republiki Krymu 11 kwietnia 2014 roku przyznaje status języków państwowych w Republice Krymu trzem językom: rosyjskiemu, ukraińskiemu i krymskotatarskiemu.

${ }^{6}$ Wydarzenia z 2014 roku na Krymie będące następstwem niezadowolenia ludności rosyjskojęzycznej półwyspu ze zmian na Ukrainie po Euromajdanie - referendum z 14 marca dotyczące przyszłego statusu półwyspu, ogłoszenie 17 marca Republiki Krymu i m. Sewastopola niezależnym i suwerennym państwem na podstawie Deklaracji Niezależności i wyników referendum, propozycja nowych władz Krymu dotycząca przyjęcia Republiki Krymu i miasta o znaczeniu federalnym Sewastopola w skład Federacji Rosyjskiej, podpisanie 18 marca umowy o przyłączeniu Krymu do Rosji - doprowadziły do oderwania Krymu od Ukrainy; Republika Krymu i miasto Sewastopol stały się jednostkami administracyjnymi (podmiotami) Federacji Rosyjskiej. Należy zaznaczyć, że Ukraina (i większość państw świata) nie uznaje secesji Krymu, a przyłączenie do Rosji uważa za okupację.

7 Zob. T.A. Olszański, Tatarzy Krymscy po aneksji półwyspu przez Rosję, w: Ośrodek Studiów Wschodnich im. Marka Karpia: Komentarze OSW nr 141, http://www.osw.waw. pl/sites/default/files/komentarze_141.pdf [dostęp: 30.06.2016]. 
Bachczysarajem - dużą muzułmańską szkołę teologiczna, medresę Zyndżyrły. Medresa dysponowała najbogatszą biblioteka, do której spływały książki w darze od chanów i bogatych mecenasów. Chanowie i członkowie ich rodzin posiadali też prywatne biblioteki. W czasie wojny rosyjsko-tureckiej (1735-1739), w 1736 roku armia rosyjska, pod dowództwem generała Christopha von Münnicha, wtargnęła do stolicy chanatu - Bachczysaraju, zniszczyła i spaliła miasto oraz pałac chanów ${ }^{8}$. Najcenniejsze biblioteki i księgozbiory zostały wówczas spustoszone. Odbudową stolicy i pałacu ze zniszczeń zajął się chan Selamet II Girej (1691-1751). Dzieło odtworzenia Krymu kontynuował chan Arsłan Girej (1692-1768), który wybudował szkołę i medresę przy Wielkim Meczecie Chan-Dżami w kompleksie pałacowym chanów krymskich w Bachczysaraju. Szkoła i medresa przy Wielkim Meczecie również posiadały książnice $\mathrm{z}$ bezcennymi zbiorami. Istnienie bibliotek w Chanacie Krymskim poświadczają Kadyaskerskie księgi, zawierające m.in. spisy książek będących w posiadaniu biblioteki pałacowej i właścicieli prywatnych?

\section{W imperium rosyjskim}

Na fali odrodzenia narodowego w drugiej połowie XIX wieku otwarto na Krymie wiele krymskotatarskich bibliotek i izb-czytelń. W 1889 roku mudarysem ${ }^{10}$ medresy Zyndżyrły został postępowy ulem (teolog i uczony) Adży Abibułła-Efendi. Ten zaprzyjaźniony z Ismailem Gasprinskim zwolennik reformy szkolnictwa muzułmańskiego postulował utworzenie takiej biblioteki medresy, w której oprócz książek do nauczania znajdowałyby się inne książki w językach orientalnych. Taką właśnie bibliotekę sam utworzył i ofiarował jej swój prywatny księgozbiór ${ }^{11}$. Według

${ }^{8}$ V.A. Volkov, V.E. Voronin, V.V. Gorskij, Voennaâ istoriâ Rossii s drevnejših vremen do konca XIX v.: Učebnoe posobie dlâ studentov pedagogičeskih vuzov, Moskva: Izdatel'stvo Prometej, 2012, s. 108, https://books.google.pl/books?id=PwaHCwAAQBAJ\&pg=PT155\&lpg=PT155\&dq=\%D0\%91\%D0\%B0\%D1\%85\%D1\%87\%D0\%B8\%D1\%81\%D0\%B 0\%D1\%80\%D0\%B0\%D0\%B9+1736\&source=bl\&ots=y4FZZcH-IC\&sig=zFUlbraoeNjAdETpEwxF8qMn4uI\&hl=pl\&sa=X\&ved=0ahUKEwij7prr9uLMAhWJHJoKHbqzA 0MQ6AEISDAF\# $\mathrm{v}=$ onepage \&q= $\%$ D0 $\% 91 \% \mathrm{D} \% \mathrm{\% B} \% \mathrm{D} 1 \% 85 \% \mathrm{D} 1 \% 87 \% \mathrm{D} 0 \% \mathrm{~B} 8 \% \mathrm{D} 1 \%$ 81\%D0\%B0\%D1\%80\%D0\%B0\%D0\%B9\%201736\&f=false [dostęp: 10.05.2016].

${ }^{9}$ L.Z. Kadyrova, Krymskotatarskie biblioteki v Krymu: istoriâ i sovremennost', „Naučnye i tehničeskie biblioteki" 2015, nr 8, s. 19, http://www.gpntb.ru/ntb/ntb/2015/8/ ntb_8_3_2015.pdf [dostęp: 10.05.2016].

${ }^{10}$ Mudarys - nauczyciel medresy, znawca metodyki jurysprudencji i norm etyczno-prawnych islamu.

${ }^{11}$ I.A. Bogdanovič, Gazeta "Perevodčik-Terdžiman" o reformah Adži Abibully èfendi v Zindžerli-medrese, „Kul'tura narodov Pričernomor'â” 2001, nr 22, s. 77, http://dspace. 
Elwiza Osmanowa w 1890 roku jej księgozbiór składał się z 800 książek i rękopisów, wśród których znajdowały się publikacje do nauczania i wydawnictwa naukowe $\mathrm{w}$ języku arabskim, tureckim, perskim i rosyjskim, podarowane przez wspomnianego mudarysa i inne osoby ${ }^{12}$.

\section{Okres władzy radzieckiej}

W latach 1923-1927 w KASRR nastąpiło ożywienie w kompletowaniu krymskotatarskiego dziedzictwa narodowego i księgozbiorów. Oprócz bibliotek pałacu chanów i medresy Zyndżyrły oraz biblioteki przy drukarni gazety „Terdżyman” istniały krymskotatarskie izby-czytelnie, które w początkowym okresie władzy radzieckiej na Krymie były wykorzystywane do niwelowania analfabetyzmu ${ }^{13}$.

Biblioteka tatarska w Symferopolu powstała przed rewolucją przy otwartej w 1872 roku tatarskiej szkole nauczycielskiej, przekształconej w 1917 roku w seminarium nauczycielskie ${ }^{14}$. Po likwidacji seminarium zachowała swoje zasoby, a od 1918 roku mieściła się kolejno na ul. Kantarnej 20 i w szkole średniej przy ul. Bałakławskiej. Posiadała wypożyczalnię, magazyn, oddział dziecięcy i dwa punkty wypożyczania książek, a od 1939 roku również czytelnię. W 1940 roku odnotowano dobry stan biblioteki, zgrany zespół i pomoc aktywu czytelniczego w pracach bibliote$\mathrm{ki}^{15}$. Pracowało w niej wówczas trzech bibliotekarzy, a księgozbiór liczył 7659 egzemplarzy ${ }^{16}$.

nbuv.gov.ua/bitstream/handle/123456789/81001/16-Bogdanovich.pdf?sequence=1 [dostęp: 10.05.2016].

12 È. Osmanov, Medrese Bahčisarâa, "Gasyrlar avazy - Èho vekov” 2014, nr 1/2, http://www.archive.gov.tatarstan.ru/magazine/go/anonymous/main/?path=mg:/ numbers/2014_1_2/10/04/ [dostęp: 10.05.2016].

${ }^{13}$ Ibidem, s. 58-59; L.Z. Kadyrova, Krymskotatarskie biblioteki v Krymu..., s. 20.

${ }^{14}$ E.V. Kostyleva, Polikul'turnoe obrazovatel'noe prostranstvo Tavričeskoj gubernii (1802-1921): usloviâ formirovaniâ, „Naučnyj vestnik Kryma” 2016, nr 1 (1), http:// nvk-journal.ru/index.php/NVK/article/view/32/html [dostęp: 10.05.2016]; R.I. Haâli, Krymskotatarskâ̂ sistema obrazovaniâ v 1917-1920 gg., "Kul'tura narodov Pričernomor'â" 2009, nr 156, s. 111-114, http://www.nbuv.gov.ua/old_jrn/Soc_Gum/KNP/156/ knp156_111-114.pdf [dostęp: 10.05.2016].

${ }^{15}$ R.I. Ušataâ, Istoriâ bibliotek goroda Simferopolâ: konec XIX - pervaâ polovina XX veka, „Kul'tura narodov Pričernomor'â" 2007, nr 98, t. 2, s. 58, http://elib.crimea.edu/ knp/vol98_2.pdf [dostęp: 10.05.2016].

16 Przytaczana jest też inna szacunkowa ilość przedwojennych zbiorów Biblioteki, wynosząca 20000 egzemplarzy. Dane dotyczące liczebności księgozbioru tuż przed okupacją oraz tuż po wyzwoleniu, a zatem dotyczące również strat w księgozbiorze w czasie wojny są sprzeczne i trudne do zweryfikowania. Zob. ibidem, s. 59. 
Spośród ogólnodostępnych bibliotek w czasie II wojny światowej biblioteka krymskotatarska ucierpiała najmniej - ocalał budynek i sprzęt, natomiast podobnie jak większość krymskich bibliotek poniosła znaczne straty w księgozbiorze. W dniu wyzwolenia Symferopola (13 kwietnia 1944 roku) księgozbiór liczył 4800 lub 7300 egzemplarzy. Biblioteka wznowiła działalność, ale już nie jako krymskotatarska, lecz jako biblioteka dzielnicy Centralnej miasta Symferopola; kilka miesięcy później nadano jej imię A.P. Czechowa ${ }^{17}$.

Po deportacji Tatarów w 1944 roku zlikwidowano wszystkie tatarskie placówki kulturalne na terenie Krymu, w tym także biblioteki. Ich księgozbiory skonfiskowano i zniszczono. Przez niemal pół wieku na Półwyspie Krymskim nie było ani jednej krymskotatarskiej biblioteki, a w krymskich bibliotekach nie było ani jednej książki w języku krymskotatarskim ${ }^{18}$.

\section{Biblioteka im. I. Gasprinskiego - ważniejsze wydarzenia z historii}

Biblioteka krymskotatarska została na nowo powołana do życia dopiero 24 września 1990 roku jako filia nr 19 Scentralizowanego Systemu Bibliotecznego dla Dorosłych Miasta Symferopola. Wtedy też przyjęła pierwszych czytelników. Jej uroczystego otwarcia dokonano w lutym 1991 roku. Pięć lat później uzyskała status biblioteki republikańskiej i nadano jej imię Ismaila Gasprinskiego ${ }^{19}$. Odtąd, już jako samodzielna instytucja podległa Ministerstwu Kultury Autonomicznej Republiki Krymu (od 2015 roku - Republiki Krymu), nosi oficjalną nazwę Republikańska Biblioteka Krymskotatarska (RBK) im. I. Gasprinskiego. Na początku praca bibliotekarzy polegała na poszukiwaniu książek, gazet i czasopism zachowanych w bibliotekach Ukrainy, Rosji, innych krajów postradzieckich

\section{${ }^{17}$ Ibidem.}

${ }^{18}$ L.Z. Kadyrova, Krymskotatarskaâ biblioteka im. I. Gasprinskogo: osnovnye aspekty deâtel'nosti, „Bibliotečnyj vestnik: Naučno-praktičeskij žurnal” 2013, nr 1 (35), s. 27, http:// gasprinskylibrary.ru/nauchno-prakticheskii-zhurnal-bibliotechnyi-vestnik-1-35-2013. html [dostęp: 10.05.2016]. Autorka podaje, że po deportacji zlikwidowano 640 bibliotek w szkołach podstawowych i 221 w szkołach średnich, 200 bibliotek w kołchozach, $30 \mathrm{w}$ rejonach i $60 \mathrm{w}$ miastach Krymu. Na wsiach zamknięto 360 czytelń, a w miastach i rejonach ponad 260 klubów.

${ }^{19}$ Ismail Bej Gaspirali (Gasprinski) (1851-1914) - pedagog, wydawca i polityk, twórca nowoczesnej świadomości narodowej Tatarów krymskich i reformator szkolnictwa. 


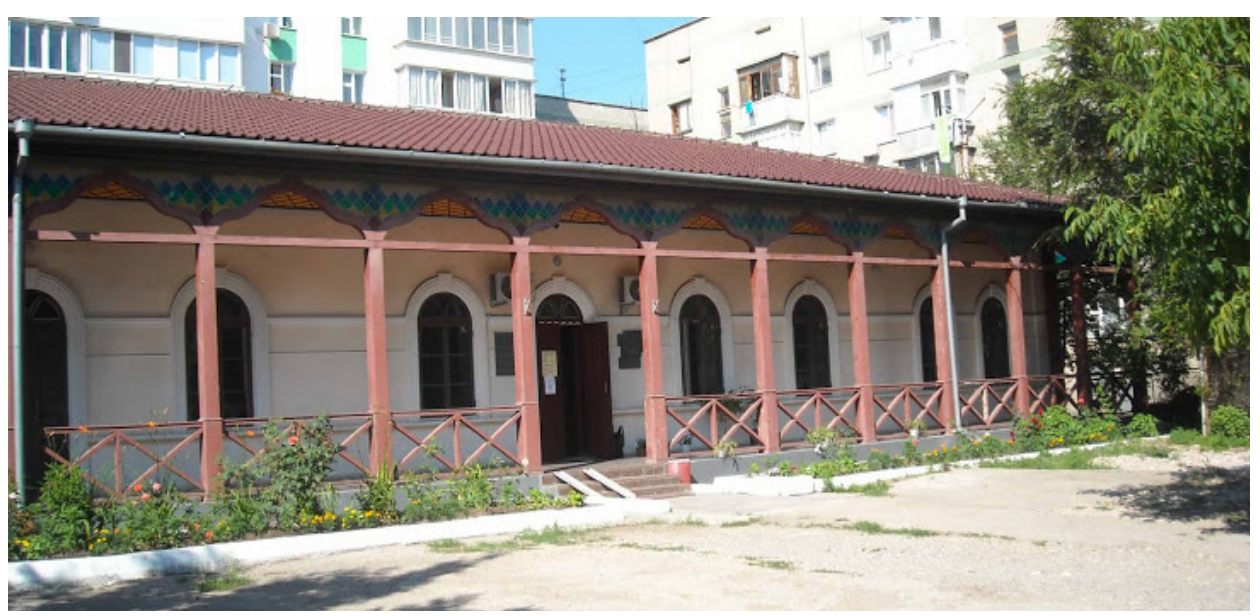

Il. 1. Krymskotatarska Republikańska Biblioteka im. I. Gasprinskiego w Symferopolu Źródło: http://4.bp.blogspot.com/_i4En7Lh0NXc/TA5TMrkZJeI/AAAAAAAAAhA/L43PYjlY6eI/S730/library+photo.JPG.

i za granicą oraz na staraniach o ich pozyskanie dla Biblioteki. Rozpoczęto też poszukiwania archiwaliów ${ }^{20}$.

Ważną rolę w tworzeniu i rozwoju Biblioteki odegrał, opracowany w 1994 roku przez Mehmeta Tütüncü, dyrektora Centrum Badawczego Turkiestanu i Azerbejdżanu (Research Center for Turkestan and Azerbaijan) w Haarlem (Holandia), projekt „Odrodzenie biblioteki krymskotatarskiej”. Był realizowany na dużą skalę od 1998 roku przy finansowym wsparciu rządu Królestwa Holandii (donacja w wysokości 240000 USD) i Międzynarodowej Fundacji „Odrodzenie” (donacja w wysokości 145000 USD) ${ }^{21}$. Realizacja projektu objęła m.in.:

- restaurację budynku Biblioteki,

- automatyzację prac bibliotecznych,

- uzupełnianie księgozbioru (wydawnictwa i kopie),

- dokształcanie bibliotekarzy,

- utworzenie ośrodka informacji,

- działalność wydawniczą (publikacje dotyczące historii i kultury Tatarów krymskich) ${ }^{22}$.

W latach 1995-1999 w skład Biblioteki wchodziła, założona w 1992 roku, Krymskotatarska Galeria Narodowa - początkowo jako oddział

20 L.Z. Kadyrova, Krymskotatarskaâ biblioteka im. I. Gasprinskogo...

${ }^{21}$ T. Kocaoglu, Crimea Education, w: Welcome to the Turkish World!, http://tudub. tripod.com/id38.html [dostęp: 10.05.2016].

${ }^{22}$ L.Z. Kadyrova, Krymskotatarskaâ biblioteka im. I. Gasprinskogo..., s. 28. 
o nazwie Muzeum Sztuk Plastycznych Tatarów Krymskich, a od 1998 roku jako filia o nazwie Muzeum Sztuki Krymskotatarskiej. W 2000 roku muzeum uzyskało odrębny status prawny i nazwę Republikańskiego Krymskotatarskiego Muzeum Sztuki ${ }^{23}$.

Wydzielenie w 2000 roku w strukturze Biblioteki Sekcji Materiałów Rękopiśmiennych i Archiwalnych ${ }^{24}$ (obecnie Oddział Książek Rzadkich, Rękopisów i Materiałów Archiwalnych) było następstwem pozyskania przez Bibliotekę rozmaitych darów. A dzięki grantowi z Ambasady USA na Ukrainie (24 000 USD) w 2001 roku uruchomiono Centrum Internetowe dla użytkowników Biblioteki ${ }^{25}$. Poza tym od 2006 roku Biblioteka jest współfundatorem nagrody Fundacji Dobroczynnej im. Bekira Czoban-zade, przyznawanej za stworzenie dzieła szczególnie ważnego dla krymskotatarskiej kultury, zaś od 2012 roku współorganizatorem Krymskiej Konferencji Naukowo-Praktycznej „Świat Bekira Czoban-zade”26.

W 2010 roku Biblioteka uruchomiła oficjalną stronę internetową ${ }^{27}$ prowadzoną w dwóch językach: krymskotatarskim i rosyjskim. W 2013 roku zrealizowano projekt „Obsługa biblioteczna użytkowników z zaburzeniami wzroku".

Przełomowy rok $2014^{28}$ przyniósł zmiany w statusie prawnym wielu instytucji, w tym również RBK. 19 sierpnia, powołując się na ogłoszenie

${ }^{23}$ V.È. Vejsova, Koncept-analiz kul'turnyh sobytij v žizni krymskih tatar na rubeže XXXXI vekov, „Kul'tura narodov Pričernomor'â” 2009, nr 161, s. 169-170, http://dspace. nbuv.gov.ua/xmlui/bitstream/handle/123456789/24516/54-Vesova.pdf?sequence=1 [dostęp: 10.05.2016]. Obecnie (od 2006 roku - Krymskotatarskie Muzeum Dziedzictwa Kulturalno-Historycznego) jest najważniejszą placówką gromadząca, przechowującą i eksponującą dzieła o znaczeniu historycznym i artystycznym oraz badającą tradycyjne dobra kultury, odrębność i bogactwo duchowe Tatarów krymskich.

${ }^{24}$ M. Alimova, Kollekcii sektora arhivnyh $i$ rukopisnyh materialov Krymskotatarskoj biblioteki im. I. Gasprinskogo, „Bibliotečnyj vestnik: Naučno-praktičeskij žurnal” 2013, nr 1 (35), s. 32, http://gasprinskylibrary.ru/nauchno-prakticheskii-zhurnalbibliotechnyi-vestnik-1-35-2013.html [dostęp: 10.05.2016].

${ }^{25} \mathrm{Krym}$ : 2 respublikanskie biblioteki otkryli besplatnye internet-centry, http://podrobnosti.ua/13786-krym-2-respublikanskie-biblioteki-otkryli-besplatnye-internet-tsentry. html [dostęp: 5.07.2016].

${ }^{26}$ E.I. Kuz'min, Gosudarstvennoe bûdžetnoe učreždenie kul'tury Respubliki Krym "Respublikanskaâ krymskotatarskaâ biblioteka im. I. Gasprinskogo", w: Respublikanskaâ biblioteka im. I. Gasprinskogo: 25 let: bibliografičeskij ukazatel', Simferopol': Respublikanskaâ krymskotatarskaâ biblioteka im. I. Gasprinskogo, 2015, s. 9-10, https://yadi. sk/d/87km4FkwjFdL7 [dostęp: 10.05.2016].

${ }^{27}$ Gosudarstvennoe bûdžetnoe učreždenie kul'tury Respubliki Krym "Respublikanskâ̂ krymskotatarskaâ biblioteka im. I. Gasprinskogo", http://gasprinskylibrary.ru/ [dostęp: 10.05.2016].

${ }^{28}$ Zob. przypis 6. 
zamieszczone na oficjalnej stronie internetowej Biblioteki, media ukraińskie podały informację o likwidacji Biblioteki. Wicedyrektor Lejla Kadyrowa zapewniła, że Biblioteka nie jest likwidowana, traci jedynie dotychczasową osobowość prawna, nadal funkcjonuje i będzie pracować $\mathrm{w}$ dotychczasowym trybie. W związku ze zmianą statusu prawnego Biblioteki opracowano dostosowany do nowych realiów statut, określono nowe zadania. Od 1 stycznia 2015 roku Biblioteka jest państwową budżetową instytucją kultury, podporządkowaną jurysdykcji Republiki Krymu i Federacji Rosyjskiej.

\section{Stan obecny}

\section{Siedziba, struktura i kadra pracownicza Biblioteki}

Biblioteka od końca 1991 roku ma stałą siedzibę w stolicy Krymu. Mieści się w parterowym zabytkowym budynku, w którym do 1910 roku znajdowała się krymskotatarska szkoła średnia (ruszdie mektebi) ${ }^{29}$. Najstarszą część - południową - zbudowano w XVI wieku, część zasadniczą w XIX wieku. W 1999 roku zakończono odnowienie budynku w ramach projektu „Odrodzenie krymskotatarskiej biblioteki”. Obecnie RBK dysponuje niewielką czytelnią dla 30 użytkowników ${ }^{30}$.

Biblioteka zatrudnia 30 pracowników, w tym 18 bibliotekarzy. Dyrektorem jest Gulnara Jagjajewa ${ }^{31}$. W strukturze jest sześć oddziałów: Oddział Informacyjno-Bibliograficzny, Oddział Metodyczny, Oddział Technologii Informacyjnych, Oddział Gromadzenia, Opracowania Dokumentów i Organizacji Katalogów, Oddział Obsługi Użytkowników oraz Oddział Książek Rzadkich, Rękopisów i Materiałów Archiwalnych.

${ }^{29}$ È. Ablâzov, Četvert' veka vozroždeniâ krymskotatarskoj kul'tury v Krymu, „Golos Kryma New" 2016, nr 4 (44), http://goloskrimanew.ru/chetvert-veka-vozrozhdeniyakryimskotatarskoy-kulturyi-v-kryimu [dostęp: 10.05.2016].

${ }^{30}$ S. Adžimambetova, Biblioteka im. I. Gasprinskogo otmečaet 20-letie, http://qha.com. ua/ru/obschestvo/biblioteka-im-i-gasprinskogo-otmechaet-20letie/79410/ [dostęp: 10.05.2016].

${ }^{31}$ Den' otkrytyh dverej v svâzi s 25-letnim ûbileem Respublikanskoj krymskotatarskoj biblioteki im. I. Gasprinskogo, Ministerstvo Kul'tury Rossijskoj Federacii. Oficial'nyj sajt, http://mkrf.ru/press-center/news/article/den-otkryityih-dverey-v-svyazi-s--letnimyubileem-respublikanskoy-kryimskotatarskoy-biblioteki-im-i-gasprinskogo/denotkryityih-dverey-v-svyazi-s--letnim-yubileem-respublikanskoy-kryimskotatarskoybiblioteki-im-i-gasprinskogo [dostęp: 10.05.2016]. 


\section{Zbiory i katalogi}

Biblioteczną kolekcję utworzył wybitny znawca literatury krymskotatarskiej, pierwszy pracownik i późniejszy dyrektor Ajder Emirow. Zalążkiem księgozbioru stała się osobista biblioteka i archiwum Basyra Gafarowa, przekazana Bibliotece w 1991 roku. Pomimo trudności, jakich nastręczało gromadzenie literatury, szczególnie w języku krymskotatarskim, w 1995 roku księgozbiór liczył już 8200 egzemplarzy, w tym 1100 w języku ojczystym (krymskotatarskim). Do zwiększenia księgozbioru przyczyniły się dary Rosyjskiej Biblioteki Państwowej (ok. 2000 książek) i Biblioteki Państwowej Republiki Uzbekistanu (ok. 300 tytułów). Obecnie w zasobach bibliotecznych znajdują się ponad 43000 dokumentów (książek, czasopism i gazet), w tym ponad 13000 egzemplarzy w języku krymskotatarskim, 8200 obcojęzycznych oraz 2200 rzadkich i innych szczególnie cennych egzemplarzy ${ }^{32}$. Jest tam też „złota kolekcja” Biblioteki, mianowicie wydane za życia autorów dzieła Ismaila Gasprinskiego, Dżafera Sejdameta, Ameta Ozenbaszły, Osmana Akczokrakły, Bekira Czoban-zade, Szewki'ego Bektore, Asana Sabri Ajwazowa, Eszrefa Szemi-zade i innych działaczy krymskotatarskiej kultury. Unikalną część zbiorów stanowią:

- fotokopie 61 tomów Kadyaskerskich ksiagg w języku osmańskim, zawierających protokoły procesów sądowych z lat 1608-1786 i stanowiących bezcenne źródło wiedzy na temat historii, gospodarki, kultury, jurysprudencji, procesów społecznych i demograficznych w Chanacie Krymskim; zapisywano w nich wszystkie sprawy prowadzone przez kadyaskerów, tj. sędziów najwyższych przy Dywanie (radzie państwa) Chanów Krymskich (oryginały znajdują się w zbiorach Rosyjskiej Biblioteki Narodowej w Sankt Petersburgu) ${ }^{33}$,

- mikrofilmy gazety „Terdżyman” („Tłumacz”) z lat1883-1918 i pierwszego w świecie muzułmańskim czasopisma dla kobiet „Alemi Nisvan” („Świat Kobiety”), wydawanych przez Gasprinskiego oraz gazet „Millet” („Naród”) i „Vatan Hadimi” („Służba Ojczyźnie”),

- książki w języku krymskotatarskim opublikowane na Krymie przed deportacją 1944 roku (w 1998 roku Rosyjska Biblioteka Państwowa przekazała RBK 907 egzemplarzy przedwojennych książek),

- komplety czasopism „Emel” (1930-1998) i „Kirim” (1918, 19571961), wydawanych przez diasporę w Rumunii i w Turcji,

- kompletny zbiór gazety „Lenin bajramy” („Leninowski Sztandar”), wydawanej w Taszkiencie (Uzbekistan) w latach 1957-1990; przez

${ }^{32}$ L.Z. Kadyrova, Krymskotatarskie biblioteki v Krymu..., s. 24.

${ }^{33}$ M. Alimova, op.cit., s. 33. 
długi okres była jedyną gazetą w języku krymskotatarskim ukazującą się na wygnaniu ${ }^{34}$,

- czasopismo literackie "Jildiz" („Gwiazda”), istniejące od 1976 roku do dziś,

- kolekcje prywatnych bibliotek pisarzy - Eszrefa Szemi-zade, Reszyta Murata, Idrisa Asanina, a także filologa Basyra Gafarowa oraz językoznawcy Useina Kurkczy i innych ${ }^{35}$.

Księgozbiór jest uzupełniany przez zakup, wymianę i dary Tatarów z Krymu i z zagranicy (z Turcji, Rumunii, USA, Anglii, Polski, Holandii, Litwy). Dynamikę przyrostu księgozbioru oraz częściowe dane statystyczne usług i wypożyczeń przedstawia poniższa tabela.

Tabela. Dynamika przyrostu księgozbioru, statystyka usług i wypożyczeń

\begin{tabular}{|c|c|c|c|c|c|c|}
\hline \multirow[b]{2}{*}{ Rok } & \multicolumn{4}{|c|}{ Liczba woluminów } & \multirow[b]{2}{*}{$\begin{array}{c}\text { Liczba } \\
\text { użytkowni- } \\
\text { ków }\end{array}$} & \multirow[b]{2}{*}{$\begin{array}{l}\text { Liczba } \\
\text { wypoży- } \\
\text { czeń }\end{array}$} \\
\hline & ogółem & $\begin{array}{c}\text { w języku } \\
\text { krymskotatar- } \\
\text { skim }\end{array}$ & $\begin{array}{c}\text { w języ- } \\
\text { kach } \\
\text { obcych }\end{array}$ & $\begin{array}{c}\text { cennych } \\
\text { (rzad- } \\
\text { kich) }\end{array}$ & & \\
\hline 1990 & - & - & - & - & - & - \\
\hline 1995 & 8200 & 1100 & b.d. & b.d. & b.d. & b.d. \\
\hline 2000 & 15000 & 4000 & b.d. & 1500 & 2000 & 30000 \\
\hline 2005 & \multicolumn{6}{|c|}{ b.d. } \\
\hline 2010 & 33000 & 10000 & b.d. & b.d. & 2200 & 55000 \\
\hline 2015 & 43000 & 13000 & 8200 & 2200 & 3564 & 77464 \\
\hline
\end{tabular}

Źródło: opracowanie własne ${ }^{36}$.

Źródłem informacji o zbiorach Biblioteki są następujące tradycyjne katalogi kartkowe:

- książek w językach krymskotatarskim, rosyjskim, ukraińskim i tureckim oraz w innych językach (alfabetyczne i rzeczowe),

- wydawnictw periodycznych,

${ }^{34}$ A. Kaźmierak, Media Tatarów krymskich - historia rozwoju, struktura, rola, "Annales Universitatis Mariae Curie-Skłodowska" 2010, t. 17,1, Sectio K, s. 144, http://webcache. googleusercontent.com/search?q=cache:Gkq6Oac8XFAJ:annales.umcs.lublin.pl/tt_p. php\%3Frok\%3D2010\%26tom\%3D17\%26sectio\%3DK\%26numer_artykulu\%3D08\%26 zeszyt $\% 3 D 1+\& c d=1 \& h l=p l \& c t=c l n k \& g l=p l \& c l i e n t=$ firefox-b [dostęp: 10.05.2016].

35 M. Alimova, op.cit., s. 32-35.

${ }^{36}$ Na podstawie publikacji: lata 1995 i 2000 - Pervaâ krymskotatarskaâ biblioteka, http://www.crimea.ru/item_info_big.htm?id=157 [dostęp: 10.05.2016]; rok 2010 S. Adžimambetova, op.cit.; rok 2015 - L.Z. Kadyrova, Krymskotatarskie biblioteki v Krymu... 
- wydawnictw ciagłych,

- dokumentów rękopiśmiennych i archiwalnych (alfabetyczny i rzeczowy),

- dokumentów epistolarnych,

- dokumentów plastycznych (dzieł sztuki).

Są też kartoteki: krajoznawcza, rzeczowa artykułów, personaliów, artykułów o Turcji oraz ilustracji. Równocześnie tworzona jest elektroniczna baza danych, która liczy obecnie ponad 67000 rekordów bibliograficznych.

\section{Działalność ponadusługowa Biblioteki ${ }^{37}$}

Biblioteka jest ważnym dla Tatarów krymskich ośrodkiem kultury, oświaty i informacji, a także centralną książnicą materiałów drukowanych, która gromadzi, opracowuje, magazynuje i udostępnia użytkownikom dokumenty i rękopisy w języku krymskotatarskim oraz literaturę o Tatarach krymskich w innych językach. Posiada najbardziej kompletną kolekcję wydawnictw krymskotatarskich na świecie.

Biblioteka jest depozytariuszem i ośrodkiem upowszechniania wiedzy o Tatarach krymskich, Karaimach, Krymczakach i innych narodach turkijskich oraz o kulturze muzułmańskiej. Spełnia też funkcję ośrodka metodycznego, służącego pomocą bibliotekom na Krymie w zakresie popularyzacji dokumentów krymskotatarskich i jest w tym przedmiocie kreatorką bibliografii zalecającej ${ }^{38}$. Wszystkie prace biblioteczne są zautomatyzowane i realizowane $\mathrm{z}$ wykorzystaniem zintegrowanego systemu bibliotecznego IRBIS ${ }^{39}$.

${ }^{37}$ Na podstawie publikacji m.in. L.Z. Kadyrowej, G.S. Jagjajewej i dokumentów dostępnych na stronie oficjalnej Biblioteki.

38 G.S. Âg'âeva, Respublikanskoj krymskotatarskoj biblioteke im. I. Gasprinskogo 25 let, „Bibliotečnoe obsluživanie krymskotatarskich pol'zovatelej: tradicii i innovacii. Metodičeskij bûlleten"' 2014, t. 11, s. 3, http://gasprinskylibrary.ru/metodicheskii-byulleten-vyp11-bibliotechnoe-obsluzhivanie-krymskotatarskikh-polzovatelei-traditsii-i [dostęp: 10.05.2016].

39 IRBIS - kompleksowe oprogramowanie umożliwiające automatyzację prac bibliotecznych, używane w bibliotekach Rosji, Białorusi i innych krajów postradzieckich, a opracowywane przez zespół specjalistów z Państwowej Publicznej Biblioteki Naukowo-Technicznej Rosji i Międzynarodowego Stowarzyszenia Użytkowników i Twórców Elektronicznych Bibliotek i Nowych Technologii Informacyjnych (Stowarzyszenia EBNIT). Zob. Sistema IRBIS 64, w: Associaciâ EBNIT, http://www.elnit.org/index.php?option=com_content\&view=article\&id=65\&Itemid=451 [dostęp: 4.06.2016]. 
Do priorytetowych zadań Biblioteki należy badanie i pomnażanie dziedzictwa narodowego Tatarów krymskich oraz narodów pokrewnych, sprzyjanie kształtowaniu się samoświadomości narodowej, szacunku do historii i kultury regionu, zapoznawanie Tatarów z ich historią, kulturą i językiem ojczystym, zwyczajami oraz tradycjami. Biblioteka zajmuje się też popularyzacją wiedzy o życiu i działalności znaczących przedstawicieli tego narodu, twórczości pisarzy, poetów, kompozytorów, twórców ludowych. Usługi świadczy nie tylko dla dorosłych, ale również dla dzieci i młodzieży, w tym dla uczniów i studentów. Użytkownicy Biblioteki biorą udział $\mathrm{w}$ licznych imprezach: wystawach, prezentacjach, wieczorach poświęconych pamięci działaczy ruchu tatarskiego.

W Bibliotece funkcjonuje Centrum Obsługi Użytkowników z Zaburzeniami Wzroku, gdzie odbywają się imprezy dla czytelników o różnym stopniu niepełnosprawności ${ }^{40}$. Centrum posiada oprogramowanie przeznaczone dla osób z niepełnosprawnością wzrokową umożliwiające korzystanie z komputera i z Internetu. Użytkownicy słabo widzący mogą korzystać z oprogramowania pozwalającego na powiększenie przekazu na ekranie i umożliwiającego jednoczesne śledzenie informacji na ekranie komputera oraz ich odsłuchiwanie za pomocą syntezatora mowy. Ze swojej strony ${ }^{41}$ centrum umożliwia dostęp do ścieżki dźwiękowej z przykładami utworów z literatury krymskotatarskiej ${ }^{42}$ na stronie internetowej Lejli Emirowej Kwiat Ojczyzny mojej... ${ }^{43}$.

W Oddziale Obsługi Użytkowników funkcjonuje Czytelnia Elektroniczna ${ }^{44}$, która umożliwia dostęp do źródeł elektronicznych Biblioteki, do Internetu oraz do katalogu elektronicznego i elektronicznych źródeł informacji. Czytelnia prowadzi również kursy obsługi komputera dla osób w wieku emerytalnym. Dla użytkowników zdigitalizowano rzadkie wydawnictwa będące w posiadaniu Biblioteki.

${ }^{40}$ GBU RK Respublikanskâ̂ krymskotatarskaâ biblioteka im. I. Gasprinskogo, w: Krymskaâ respublikanskaâ universal'naâ biblioteka im. I. Â. Franko, http://franco.crimealib.ru/ bibliotekarju/biblioteki-kryma/krymskotatarskaya-biblioteka-im-i-gas.html [dostęp: 10.05.2016].

${ }^{41}$ Centr obsluživaniâ pol'zovatelej s ograničennymi vozmožnostâmi, http://gasprinskylibrary.ru/ru/tsentr-obsluzhivaniya-polzovatelei-c-ogranichennymivozmozhnostyami.html [dostęp: 10.05.2016].

${ }^{42}$ Zvukovâ̂ dorožka, http://leylaemir.org/rus/sound-gallery/sound-gallery.php [dostęp: 10.05.2016].

${ }^{43}$ Cvet Rodiny moej..., http://leylaemir.org/rus/home.html [dostęp: 10.05.2016].

${ }^{44}$ Cennye redkie izdaniâ na èlektronnyh nositelâh, http://gasprinskylibrary.ru/razdel-novostei/elektronnyi-chitalnyi-zal [dostęp: 10.05.2016]. 
Z powodu braku wyspecjalizowanej krymskotatarskiej biblioteki dla dzieci we wrześniu 2015 roku w RBK otwarto Centrum Czytelnictwa Krymskotatarskiego dla Dzieci „Czokraczyk” („Źródełko”) ${ }^{45}$. Zadaniem centrum jest zachęcanie dzieci do czytania książek w języku krymskotatarskim. Centrum raz w miesiącu w czytelni realizowane zajęcia dla dzieci w wieku przedszkolnym i dla uczniów do 15. roku życia. Planowane są zajęcia wyjazdowe w szkołach i przedszkolach, prowadzone we współpracy z nauczycielami języka krymskotatarskiego. Na stronie internetowej Biblioteki od 2011 roku prowadzona jest "Stronka dla dzieci"46.

Celem działalności informacyjno-bibliograficznej RBK jest zaspokajanie potrzeb informacyjnych indywidualnych użytkowników, a także różnych organizacji, instytucji, przedsiębiorstw i firm. Oddział Informacyjno-Bibliograficzny zajmuje się sporządzaniem tematycznych zestawień bibliograficznych. Przykładowo: wykaz literatury z zakresu historii teatru krymskotatarskiego od 1907 roku, wykaz podręczników języka krymskotatarskiego z lat 1910-1944; wykazy poświęcone pedagogom, pisarzom, poetom, dziennikarzom, artystom, działaczom kultury oraz krymskotatarskim strojom narodowym; zarejestrowano spis bajek, legend i literatury dziecięcej w języku krymskotatarskim oraz w przekładzie na ten język. Poza tym na stronie internetowej Biblioteki regularnie aktualizowany jest wykaz nabytków.

Z kolei Oddział Książek Rzadkich, Rękopisów i Materiałów Archiwalnych zajmuje się badaniem i opracowaniem dokumentów archiwalnych oraz poszukiwaniem, pozyskiwaniem i udostępnianiem archiwaliów osobistych znanych pisarzy, uczonych i działaczy krymskotatarskiego ruchu narodowego ${ }^{47}$. Obecnie posiada 600 kolekcji (ponad 4000 jednostek inwentarzowych $)^{48} \mathrm{w}$ postaci rękopisów, ksero- i fotokopii, taśm magnetofonowych oraz zapisów na elektronicznych nośnikach informacji. Z tych zasobów korzystają krymscy i zagraniczni badacze i uczeni. Na ich podstawie powstało dziewięć publikacji książkowych i przygotowywane są kolejne $^{49}$.

Jako ośrodek metodyczny dla bibliotek na Krymie obsługujących ludność krymskotatarską i popularyzujących literaturę narodową,

${ }^{45} \mathrm{~V}$ Ak"mesdžite otktrylsâ Centr krymskotatarskogo detskogo čteniâ (FOTO), http:// avdet.org/node/14487 [dostęp: 10.05.2016].

${ }^{46}$ Stranička dlâ detej, http://gasprinskylibrary.ru/stranichka-dlya-detei.html [dostęp: 10.05.2016].

${ }^{47}$ M. Alimova, op.cit., s. 32.

48 E.I. Kuz'min, op.cit., s. 9.

${ }^{49}$ L.Z. Kadyrova, Krymskotatarskie biblioteki v Krymu..., s. 23. 
RBK koordynuje działalność tych bibliotek, udziela im pomocy metodycznej i organizacyjnej oraz prowadzi badania socjologiczne wśród użytkowników i pracowników bibliotek. Wyniki badań stanowią podstawę do opracowania rekomendacji, służących poprawie jakości obsługi, aktywizacji działalności bibliotek, efektywnego wykorzystania nowoczesnych technologii i doskonalenia zawodowego bibliotekarzy. Szczególną uwagę poświęca się usługom bibliotek publicznych w 300 miejscowościach, w których mieszkają duże skupiska Tatarów krymskich. Opracowywane są materiały dotyczące popularyzacji literatury krymoznawczej.

W latach 1999-2003 Biblioteka była głównym organizatorem międzynarodowych konferencji „Biblioteka jako centrum dialogu kultur w społeczeństwie wieloetnicznym”. Główny wątek tematyczny to usługi biblioteczno-informacyjne w regionach wieloetnicznych. Materiały z tych konferencji opublikowano w pięciu tomach monograficznych pod wspólnym tytułem Bibliotekarstwo i krajoznawstwo.

Biblioteka prowadzi też działalność wydawniczą. Co roku wydaje „Kalendarz znamiennych i pamiętnych dat narodu krymskotatarskiego". W serii Biblioteki "Źródło wiedzy" publikowane są książki dotyczące historii i kultury narodu krymskotatarskiego. Z udziałem pracowników Biblioteki wydano m.in.: Szkice z historii krymskotatarskiej kultury (1921-1941), słownik biobibliograficzny Działacze krymskotatarskiej kultury (1921-1944) autorstwa Dmitrija Ursu, antologię klasycznej poezji krymskotatarskiej XV-XIX wieku Marzenia różanego ogrodu, Zbiór prac A.N. Samojtowicza o Krymie $i$ Tatarach krymskich (oprac. Elena Emirowa i Ajder Emirow), Artykuty literaturoznawcze Eszrefa Szemi-Zade, a także książki Wiktora Gankiewicza o I. Gasprinskim (Nauczyciel nauczycieli i W stużbie prawdzie i oświacie).

\section{Współpraca z innymi bibliotekami i instytucjami kultury}

Od założenia Biblioteki dobrze układała się jej współpraca z instytucjami krajowymi i zagranicznymi. Ogromną wartość w kompletowaniu księgozbioru miały książki pozyskane z darów Rosyjskiej Biblioteki Państwowej (2000 tytułów) i z Biblioteki Państwowej Republiki Uzbekistanu (300 tytułów). Trudno też przecenić wkład diaspory krymskotatarskiej, która podarowała Bibliotece ok. 5000 dokumentów.

Dużą pomoc w przygotowaniu i w pozyskiwaniu grantów oraz w tłumaczeniach na język angielski okazała Bibliotece wolontariuszka Korpusu Pokoju Barbara Wieser, która pracowała tam w latach 2009-2013. 
Z jej udziałem i przy wsparciu finansowym Korpusu Pokoju USA na Ukrainie zrealizowano projekty: „Pomoc bibliotek Krymu w zachowaniu i odrodzeniu języka krymskotatarskiego", "Rozwój wolontariatu w bibliotekach Krymu”, "Cyfryzacja gazety «Terdżyman»" i 10 seminariów dla krymskich bibliotekarzy ${ }^{50}$. Na stronie RBK Wieser prowadziła blog $\mathrm{w}$ języku angielskim o działalności Biblioteki ${ }^{51}$.

W Koncepcji rozwoju Biblioteki na lata 2011-2015, w rozdziale zatytułowanym Rozwój kontaktów międzynarodowych wyznaczono następujące kierunki działania ${ }^{52}$ :

- rozwój współpracy z bibliotekami USA, Turcji, Polski, Rumunii, Rosji, Uzbekistanu, Kazachstanu, Kirgizji, Azerbejdżanu i innymi dużymi bibliotekami zagranicznymi,

- rozwój wzajemnych związków z diasporą krymskotatarska,

- rozwój współpracy z siostrzaną biblioteką publiczną miasta Bloomfield w stanie Indiana (USA),

- rozwój kontaktów z międzynarodowymi fundacjami dobroczynnymi.

Po aneksji, wskutek izolacji Krymu, osłabły kontakty ze światem zachodnim. Rozszerzyła się natomiast współpraca z bibliotekami narodowymi turkijskich narodów byłego ZSRR (Tatarstanu, Baszkortostanu, Uzbekistanu, Azerbejdżanu Kazachstanu, Kirgizji, Czuwaszji, Republiki Ałtaju) oraz z bibliotekami dla niewidomych i niedowidzących w Sankt Petersburgu, Czelabińsku i w Karelii.

\section{Zakończenie}

Republikańska Biblioteka Krymskotatarska im. I. Gasprinskiego jest obecnie jedną z 16 jednostek w sieci krymskotatarskich bibliotek na Półwyspie Krymskim ${ }^{53}$. Jej pracownicy realizują misję odbudowy wartości duchowych i kulturalnych leżących u podstaw

${ }^{50}$ I. Bowman, A Volunteer in Crimea: An Interview with Barbara Wieser, w: International Committee for Crimea, Inc, http://www.iccrimea.org/reports/wieser-interview. html [dostęp: 10.05.2016].

${ }^{51}$ Crimean Tatar Gasprinskiy Library. Blog Archive, http://crimeantatarlibrary.blogspot.com/ [dostęp: 10.05.2016].

${ }^{52}$ Koncepciâ razvitiâ Krymskogo respublikanskogo učreždeniâ "Krymskotatarskaâ biblioteka im. I. Gas-prinskogo" (2011-2015 gg.), Simferopol': Respublikanskaâ krymskotatarskaâ biblioteka im. I. Gasprinskogo, 2011, s. 27-28, http://documents.tips/ documents/557fb34fd8b42a36118b465c.html [dostęp: 10.05.2016].

${ }^{53}$ L.Z. Kadyrova, Krymskotatarskie biblioteki v Krymu..., s. 21-22. 
samoświadomości i godności narodowej Tatarów krymskich. Taki jest bowiem nakaz tradycji.

Jakkolwiek w oficjalnej nazwie Biblioteki nie ma określenia „,narodowa", to jednak zadania i funkcje, jakie spełnia, jednoznacznie wskazują na jej narodowy charakter. Należą do nich w szczególności:

- gromadzenie, przechowywanie i udostępnianie możliwie najpełniejszego zbioru dokumentów w języku krymskotatarskim i dokumentów o Tatarach krymskich w innych językach,

- opracowanie krymskotatarskiej bibliografii narodowej,

- koordynacja działalności krymskich bibliotek w zakresie obsługi ludności krymskotatarskiej; udzielanie im metodycznej i praktycznej pomocy,

- popularyzacja wiedzy o Krymie.

W tym kontekście zwraca uwagę zapis w punkcie 20 statutu RBK o obowiązku gromadzenia, ewidencji bibliograficznej i stałym przechowywaniu egzemplarza obowiązkowego dokumentów krymskotatarskich ${ }^{54}$. Komponent „republikańska” w nazwie, odnoszący się do Republiki Kry$\mathrm{mu}$, pośrednio sygnalizuje ten charakter.

\section{Bibliografia}

Ablâzov È., Četvert' vekavozrożdeniâkrymskotatarskojkul'turyv Krymu ,,'Golos Kryma New" 2016, nr 4 (44), http://goloskrimanew.ru/chetvert-veka-vozrozhdeniyakryimskotatarskoy-kulturyi-v-kryimu [dostęp: 10.05.2016].

Adžimambetova S., Biblioteka im. I. Gasprinskogo otmečaet 20-letie, w: QHA, http:// qha.com.ua/ru/obschestvo/biblioteka-im-i-gasprinskogo-otmechaet-20letie/79410/ [dostęp: 10.05.2016].

Âg'âeva G.S., Respublikanskoj krymskotatarskoj biblioteke im. I. Gasprinskogo 25 let, „Bibliotečnoe obsluživanie krymskotatarskich pol'zovatelej: tradicii i innovacii. Metodičeskij bûlleten'"' 2014, nr 11, s. 3-6, http://gasprinskylibrary.ru/ metodicheskii-byulleten-vyp11-bibliotechnoe-obsluzhivanie-krymskotatarski kh-polzovatelei-traditsii-i [dostęp: 10.05.2016].

Alimova M., Kollekcii sektora arhivnyh i rukopisnyh materialov Krymskotatarskoj biblioteki im. I. Gasprinskogo, „Bibliotečnyj vestnik: Naučno-praktičeskij žurnal” 2013, nr 1 (35), s. 32-36, http://gasprinskylibrary.ru/nauchno-prakticheskiizhurnal-bibliotechnyi-vestnik-1-35-2013.html [dostęp: 10.05.2016].

Bogdanovič I.A., Gazeta "Perevodčik-Terdžiman” o reformah Adži Abibully èfendi v Zindžerli-medrese, „Kul'tura narodov Pričernomor'â" 2001, nr 22, s. 76-78,

${ }^{54}$ Ustav Gosudarstvennogo bûdžetnogo učreždeniâ kul'tury Respubliki Krym "Respublikanskaâ krymskotatarskaâ biblioteka im. I. Gasprinskogo", Simferopol' 2014, s. 2, https:// yadi.sk/d/PzolQqMxhk9nW [dostęp: 10.05.2016]. 
http://dspace.nbuv.gov.ua/bitstream/handle/123456789/81001/16-Bogdanovich.pdf?sequence $=1$ [dostęp: 10.05.2016].

Bowman I., A Volunteer in Crimea: An Interview with Barbara Wieser, w: International Committee for Crimea, Inc, http://www.iccrimea.org/reports/wieser-interview.html [dostęp: 10.05.2016].

Centr obsluživaniâ pol'zovatelej s ograničennymi vozmožnostâmi, http://gasprinskylibrary.ru/ru/tsentr-obsluzhivaniya-polzovatelei-c-ogranichennymivozmozhnostyami.html [dostęp: 10.05.2016].

Chazbijewicz S., Awdet czyli powrót. Walka polityczna Tatarów krymskich o zachowanie tożsamości narodowej i niepodległość państwa po II wojnie światowej, Olsztyn 2001.

Chazbijewicz S., Tatarzy krymscy: Walka o naród i wolna ojczyznę, Poznań-Września 2001.

Ciesielski S., Masowe deportacje ludności w ZSRR: Deportacje z Krymu, w: Dzieje Najnowsze. Serwis historyczny dotyczacy historii Polski, Rosji, Europy Wschodniej, http://www.sciesielski.republika.pl/sov-dep/krym1.html\#1 [dostęp: 10.05.2016].

Cennye redkie izdaniâ na èlektronnyh nositelâh, http://gasprinskylibrary.ru/razdel-novostei/elektronnyi-chitalnyi-zal [dostęp: 10.05.2016].

Crimean Tatar Gasprinskiy Library. Blog Archive, http://crimeantatarlibrary.blogspot.com/ [dostęp: 10.05.2016].

Cvet Rodiny moej..., http://leylaemir.org/rus/home.html [dostęp: 10.05.2016].

Den' otkrytyh dverej v svâzi s 25-letnim ûbileem Respublikanskoj krymskotatarskoj biblioteki im. I. Gasprinskogo, Ministerstvo Kul'tury Rossijskoj Federacii. Oficial'nyj sajt, http://mkrf.ru/press-center/news/article/den-otkryityih -dverey-v-svyazi-s--letnim-yubileem-respublikanskoy-kryimskotatarskoybiblioteki-im-i-gasprinskogo/den-otkryityih-dverey-v-svyazi-s--letnimyubileem-respublikanskoy-kryimskotatarskoy-biblioteki-im-i-gasprinskogo [dostęp: 10.05.2016].

GBU RK Respublikanskaâ krymskotatarskaâ biblioteka im. I. Gasprinskogo, w: Krymskâ̂ respublikanskâa universal'naâ biblioteka im. I.Â. Franko, http://franco.crimealib.ru/bibliotekarju/biblioteki-kryma/krymskotatarskaya-biblioteka-im-i-gas. html [dostęp: 10.05.2016].

Gosudarstvennoe bûdžetnoe učreždenie kul'tury Respubliki Krym „Respublikanskâ̂ krymskotatarskaâ biblioteka im. I. Gasprinskogo", http://gasprinskylibrary.ru/ [dostęp: 10.05.2016].

Haâli R.I., Krymskotatarskâ̂ sistema obrazovaniâ v 1917-1920 gg., „Kul'tura narodov Pričernomor'â" 2009, nr 156, s. 111-114, http://www.nbuv.gov.ua/old_jrn/ Soc_Gum/KNP/156/knp156_111-114.pdf [dostęp: 10.05.2016].

Kadyrova L.Z., Krymskotatarskaâ biblioteka im. I. Gasprinskogo: osnovnye aspekty deâtel'nosti, „Bibliotečnyj vestnik: Naučno-praktičeskij žurnal” 2013, nr 1 (35), s. 27-31, http://gasprinskylibrary.ru/nauchno-prakticheskii-zhurnalbibliotechnyi-vestnik-1-35-2013.html [dostęp: 10.05.2016].

Kadyrova L.Z., Krymskotatarskie biblioteki v Krymu: istoriâ $i$ sovremennost', „Naučnye i tehničeskie biblioteki" 2015, nr 8, s. 18-30, http://www.gpntb.ru/ntb/ ntb/2015/8/ntb_8_3_2015.pdf [dostęp: 10.05.2016]. 
Kaźmierak A., Media Tatarów krymskich - historia rozwoju, struktura, rola, „Annales Universitatis Mariae Curie-Skłodowska" 2010, t. 17,1, Sectio K, s. 131-158, http://webcache.googleusercontent.com/search?q=cache:Gkq6Oac8XFAJ:annales.umcs.lublin.pl/tt_p.php\%3Frok\%3D2010\%26tom\%3D17\%26sectio\%3DK\%26numer_artykulu\%3D08\%26zeszyt\%3D1+\&cd=1\&hl=pl\&ct=clnk\&gl=pl\& client=firefox-b [dostęp: 10.05.2016].

Kocaoglu T., Crimea Education, w: Welcome to the Turkish World!, http://tudub.tripod.com/id38.html [dostęp: 10.05.2016].

Koncepciâ razvitiâ Krymskogo respublikanskogo učreždeniâ "Krymskotatarskaâ biblioteka im. I. Gas-prinskogo" (2011-2015 gg.), Simferopol': Respublikanskaâ krymskotatarskaâ biblioteka im. I. Gasprinskogo, 2011, http://documents.tips/ documents/557fb34fd8b42a36118b465c.html [dostęp: 10.05.2016].

Kostyleva E.V., Polikul'turnoe obrazovatel'noe prostranstvo Tavričeskoj gubernii (1802-1921): usloviâ formirovaniâ, „,Naučnyj vestnik Kryma” 2016, nr 1 (1), http:// nvk-journal.ru/index.php/NVK/article/view/32/html [dostęp: 10.05.2016].

Krym: 2 respublikanskie biblioteki otkryli besplatnye internet-centry, http://podrobnosti.ua/13786-krym-2-respublikanskie-biblioteki-otkryli-besplatnye-internettsentry.html [dostęp: 5.07.2016].

Kuz'min E.I., Gosudarstvennoe bûdžetnoe učreždenie kul'tury Respubliki Krym „Respublikanskaâ krymskotatarskaâ biblioteka im. I. Gasprinskogo", w: Respublikanskaâ biblioteka im. I. Gasprinskogo: 25 let: bibliografičeskij ukazatel', Simferopol': Respublikanskaâ krymskotatarskaâ biblioteka im. I. Gasprinskogo, 2015, s. 7-11, https://yadi.sk/d/87km4FkwjFdL7 [dostęp: 10.05.2016].

Olszański T.A., Tatarzy Krymscy po aneksji pótwyspu przez Rosję, w: Ośrodek Studiów Wschodnich im. Marka Karpia: Komentarze OSW nr 141, http://www.osw.waw. pl/sites/default/files/komentarze_141.pdf [dostęp: 30.06.2016].

Osmanov È., Medrese Bahčisaraâ, "Gasyrlar avazy - Ěho vekov" 2014, nr 1/2, http:// www.archive.gov.tatarstan.ru/magazine/go/anonymous/main/?path=mg:/ numbers/2014_1_2/10/04/ [dostęp: 10.05.2016].

Pervaâ krymskotatarskaâ biblioteka, w: Crimea.ru: Informacionnyj Server „Krym dlâ rossiân", http://www.crimea.ru/item_info_big.htm?id=157 [dostęp: 10.05.2016].

Sistema IRBIS 64, w: Associaciâ EBNIT, http://www.elnit.org/index.php?option=com_content\&view=article\&id=65\&Itemid=451 [dostęp: 4.06.2016].

Stranička dlâ detej, http://gasprinskylibrary.ru/stranichka-dlya-detei.html [dostęp: 10.05.2016].

Ustav Gosudarstvennogo bûdžetnogo učreždeniâ kul'tury Respubliki Krym „Respublikanskaâ krymskotatarskâa biblioteka im. I. Gasprinskogo", Simferopol', 2014, https://yadi.sk/d/PzolQqMxhk9nW [dostęp: 10.05.2016].

Ušataâ R.I., Istoriâ bibliotek goroda Simferopolâ: konec XIX - pervaâ polovina XX veka, „Kul'tura narodov Pričernomor'â" 2007, nr 98, t. 2, s. 6-188, http://elib.crimea. edu/knp/vol98_2.pdf [dostęp: 10.05.2016].

$V A k^{\prime \prime}$ mesdžite otktrylsâ Centr krymskotatarskogo detskogo čteniâ (FOTO), http:// avdet.org/node/14487 [dostęp: 10.05.2016].

Vejsova V.E.., Koncept-analiz kul'turnyh sobytij v žizni krymskih tatar na rubeže XXXXI vekov, „Kul'tura narodov Pričernomor'â” 2009, nr 161, s. 169-170, http:// 
dspace.nbuv.gov.ua/xmlui/bitstream/handle/123456789/24516/54-Vesova. pdf?sequence=1 [dostęp: 10.05.2016].

Volkov V.A., Voronin V.E., Gorskij V.V., Voennaâ istoriâ Rossii s drevnejših vremen do konca XIX v.: Učebnoe posobie dlâ studentov pedagogičeskih vuzov, Moskva: Izdatel'stvo Prometej, 2012, https://books.google.pl/books?id=PwaHCwAAQBA$\mathrm{J} \& \mathrm{pg}=\mathrm{PT} 155 \& \mathrm{lpg}=\mathrm{PT} 155 \& \mathrm{dq}=\% \mathrm{D} 0 \% 91 \% \mathrm{D} 0 \% \mathrm{~B} 0 \% \mathrm{D} 1 \% 85 \% \mathrm{D} 1 \% 87 \% \mathrm{D} 0 \% \mathrm{~B} 8 \%$ D1\%81\%D0\%B0\%D1\%80\%D0\%B0\%D0\%B9+1736\&source=bl\&ots=y4FZZcH-IC\&sig=zFUlbraoeNjAdETpEwxF8qMn4uI\&hl=pl\&sa=X\&ved=0ahUKEwij7p rr9uLMAhWJHJoKHbqzA0MQ6AEISDAF\# $\mathrm{v}=$ onepage\&q=\%D0\%91\%D0\%B0 \%D1\%85\%D1\%87\%D0\%B8\%D1\%81\%D0\%B0\%D1\%80\%D0\%B0\%D0\%B9\%20 1736\&f=false [dostęp: 10.05.2016].

Zvukovaâ dorožka, http://leylaemir.org/rus/sound-gallery/sound-gallery.php [dostęp: 10.05.2016].

\title{
BARBARA JANCZAK
}

\section{Crimean Tatar Library in Simferopol}

\begin{abstract}
Aвstract. The article is an attempt to present the process of revival of the Crimean Tatar ethnic minority's national library in the multiethnic society of Crimea. The most important events from the over 25-year-long history of the Library are discussed alongside with a description of its current structure and functions, procedures and activities, including available services, library processes, as well as its educational, methodological, scientific and editorial activity.
\end{abstract}

Key words: Crimea, Crimean Tatars, Ismail Gasprinsky Republican Crimean Tatar Library, library functions, library services. 